\title{
REPRESENTATION OF THE STRESS STATE OF SOME ORTHOTROPIC MATERIALS BY THREE HARMONIC FUNCTIONS OF THREE VARIABLES
}

\author{
Victor Revenko
Pidstryhach Institute for Applied Problems of Mechanics and Mathematics, National Academy of Sciences of Ukraine, Lviv, Ukraine

\begin{abstract}
Summary. The model of an orthotropic deformable body based on the representation of stresses in terms of displacements is considered. The method of integration of three equations of the elastic equilibrium is used, based on the elimination of separate displacements. Problems related to the elimination of unnecessary functions from the representation of the general solution of the equations of the theory of elasticity are considered. Criteria are found that determine such a class of orthotropic materials that their stress-strain state can be expressed in terms of two functions. One function satisfies the equation of the second order in partial derivatives, and the other of the fourth order. It is established that the equation of the fourth order, in the general case, is not decomposed into two operator factors. Criteria were found for the expansion of a fourth-order equation into the product of two second-order equations. An equation has been written that must be satisfied by the elastic constants of an orthotropic material. The expression of deformations and stresses by introduced harmonic functions was written down.
\end{abstract}

Key words: orthotropic materials, equilibrium equations, displacement, stresses, shear modules.

Statement of the problem and analysis of the available investigation results. Orthotropic materials are widely used in various elements of building, engineering and technological structures [1,2]. Mathematical calculations of elastic equilibrium of prismatic orthotropic bodies have been carried out since the middle of the nineteenth century [2]. Mainly simple stress states of orthotropic prismatic bodies bending and twisting without using the general solution of the orthotropic body equations were investigated. Analytical methods for calculating orthotropic materials by means of symbolic calculations are considered in paper [3]. In order to simplify the investigation of stress distribution, it is necessary to construct general representation of the stress state in orthotropic body described by three equilibrium equations:

$$
L_{\mathrm{j}} \mathrm{u}_{\mathrm{j}}+\frac{\partial}{\partial x_{j}} \sum_{k=1, k \neq j}^{3} D_{j k} \frac{\partial}{\partial x_{k}} \mathrm{u}_{\mathrm{k}}=0 \quad L_{\mathrm{j}}=\sum_{k=1}^{3} \mathrm{~T}_{j k} \frac{\partial^{2}}{\partial x_{k}^{2}}, \quad j=\overline{1,3},
$$

where the values of elastic constants $D_{j k}, \mathrm{~T}_{j k}$ are given in [4].

The coefficients of equations system (1) contain 9 independent constants $B_{\mathrm{kk}}=T_{\mathrm{kk}}$, $G_{\mathrm{kj}}=T_{\mathrm{kj}}, B_{k j}, k \neq j, k, j=\overline{1,3}$ [4]. Changing these constants, various orthotropic, as well as transversely isotropic and isotropic materials can be described. Representations of the solution of equations (1) by three functions that satisfy the second-order equations in partial derivatives are found for transversely isotropic materials in [5,6]. We know the solution of equations (1) for orthotropic body by three functions [7], each of which satisfies the equation of the sixth 
order in partial derivatives, so that there are two additional functions. Elimination of redundant functions from the general representation of solution is complex mathematical problem. Thus, the well-known solution of Lame equations of the theory of elasticity isotropic body obtained in 1932 by Papkovich and Neiber [8] independently, contains one extra function and it is as follows

$$
\mathbf{u}=\bar{\psi} \quad \frac{1}{4(1 \quad v)} \operatorname{grad}\left[\Psi+x \psi_{1}+y \psi_{2}+z \psi_{3}\right]
$$

where $\bar{\psi}=\psi_{1} \mathbf{i}+\psi_{2} \mathbf{j}+\psi_{3} \mathbf{k}$ is vector, $\psi_{j}, j=\overline{1,3}, \Psi$ are four independent harmonic functions, $\mathrm{V}$ is Poisson's ratio. It should be noted that in order to solve the known problem of isotropic prism twisting, it is necessary to use all four functions (2). In paper [9], the general representation of the stress state of isotropic body which does not contain redundant functions is constructed.

$$
\mathbf{u}=\operatorname{grad} P \quad 4(1 \quad v) \Phi \mathbf{k}+\operatorname{rot} Q \mathbf{k}
$$

where $\mathrm{P}=z \Phi+\Psi ; \Phi, \Psi, Q$ are three harmonic functions. It is proved that any solution of Lame's equations can be represented in the form (3).

Representation of the equilibrium equations solution for a wide class of orthotropic materials, which does not contain redundant functions is given in papers $[4,10]$.

The purpose of research is to construct the mathematical solution of the equation system (1), for combinations of orthotropic coefficients which are not considered in $[4,10]$ and to find orthotropic materials whose stress-strain state can be expressed by harmonic functions.

Construction of the solution of equation system describing elastic equilibrium in orthotropic theory of elasticity. Let us consider the stress-strain state (SSS) of statically loaded three-dimensional orthotropic body. Let us use the matrix of elastic orthotropic coefficients in Cartesian coordinate system $\left(x_{1}=x, x_{2}=y, x_{3}=z\right)$ and write down the representation of stress components by deformations in compact form [4]

$$
\sigma_{\mathrm{j}}=\sum_{k=1}^{3} B_{\mathrm{j} k} \varepsilon_{k}, \quad \tau_{k j}=G_{k j} \gamma_{k j}, k \neq j, k, j=\overline{1,3},
$$

where the values of coefficients $B_{j k}, B_{j k}=B_{k j}$ of the orthotropic stiffness matrix are given in [4], $G_{k j}$ are the shear moduli of the orthotropic material [1]. Deformation components $\gamma_{k j}$, $\varepsilon_{j} \equiv \gamma_{j j}$ are expressed by known Cauchy relations $[1,2]$

$$
\varepsilon_{j}=\frac{\partial u_{j}}{\partial x_{j}}, \quad j=\overline{1,3} \quad \gamma_{k j}=\frac{\partial u_{k}}{\partial x_{j}}+\frac{\partial u_{j}}{\partial x_{k}}, k, j=\overline{1,3}, k \neq j \text {. }
$$

After mathematical transformations, we simplify equation (1) to the system of three differential equations in partial derivatives [4] 


$$
\frac{\partial}{\partial x_{j}} \mathrm{~L}_{\mathrm{k}}^{1} \mathrm{u}_{\mathrm{k}}=\frac{\partial}{\partial x_{k}} \mathrm{~L}_{\mathrm{j}}^{1} \mathrm{u}_{\mathrm{j}}, \quad k \neq j, k, j=\overline{1,3}
$$

where operators ${ }^{1}{ }_{j}$ are as follows

$$
\mathrm{L}_{\mathrm{j}}^{1}=D_{k m} L_{j}-D_{j k} D_{j m} \frac{\partial^{2}}{\partial x_{j}^{2}}, k \neq j \neq m, j, k, m=\overline{1,3} .
$$

It is shown in paper [4] that if all operators ${ }^{1}{ }_{j}^{1}$ given by relations (7) are not equivalent to each other, then the solution of the system of equations (1) can be presented as

$$
\mathrm{u}_{\mathrm{j}}=\frac{\partial}{\partial x_{j}} \prod_{k \neq j} \mathrm{~L}_{\mathrm{k}}^{1} \Phi
$$

where $\Phi$ is the unknown displacement function satisfying the sixth-order equation with partial derivatives. It is also determined that representation (8) is not fulfilled in case when one of the conditions $\mathrm{L}_{\mathrm{k}}^{1}=s_{1} \mathrm{~L}_{\mathrm{j}}^{1}, k \neq j, k, j=\overline{1,3}$ is valid for operators (7).

Let us consider the case omitted in [4], when the dependences are satisfied for operators

$$
\mathrm{L}_{2}^{1}=s_{1} \mathrm{~L}_{1}^{1}, \mathrm{~L}_{3}^{1} \neq s_{2} \mathrm{~L}_{1}^{1}
$$

where $s_{k}, s_{k} \in R, k=\overline{1,2}$ are unknown parameters. Let us divide the first operator equation (9) into coefficients near the derivatives $\frac{\partial^{2}}{\partial x_{3}^{2}}$, equate the expressions near the same derivatives, and derive three equations

$$
D_{12} \kappa_{1}^{-1}=B_{11}-G_{12} \zeta_{1}^{-1}, \quad D_{12} \kappa_{1}=B_{22}-G_{12} \zeta_{1}, \quad s_{1}=\zeta_{1} \kappa_{1}^{-1},
$$

where $\kappa_{1}=\frac{D_{23}}{D_{13}}, \zeta_{1}=\frac{G_{23}}{G_{13}}$. After multiplying the first and second equ
quadratic equation by the desired parameter $\zeta_{1}$
\[ B_{11} G_{12} \zeta_{1}^{2}-\left(B_{11} B_{22}+G_{12}^{2}-D_{12}^{2}\right) \zeta_{1}+B_{22} G_{12}=0 . \]

From the solution of equations (10), (11) we determine

$$
\zeta_{1}=\frac{b \pm \sqrt{D}}{2 B_{11} \mathrm{G}_{12}}>0 \quad \kappa_{1}=\frac{B_{22}-\zeta_{1} G_{12}}{D_{12}},
$$

where $b=B_{11} B_{22}+G_{12}^{2}-D_{12}^{2}, D=b^{2}-4 B_{11} B_{22} G_{12}^{2}, D \geq 0$. 
If $D \geq 0$, then the dependent parameters will be $\zeta_{1}, \kappa_{1}, G_{23}, D_{23}, s_{1}$, which are determined from equations (10) - (12). Let us choose independent parameters $B_{11}, D_{12}, G_{12}, B_{22}, \mathrm{~B}_{33}, G_{13}, D_{13}$ - only 7 orthotropy coefficients.

It follows from the above mentioned that the operator equation (9) will be satisfied if the following conditions are true for the orthotropy coefficients:

$$
\frac{G_{23}}{G_{13}} G_{12}=B_{22}-D_{12} \frac{D_{23}}{D_{13}}, \frac{G_{13}}{G_{23}} G_{12}=B_{11}-D_{12} \frac{D_{13}}{D_{23}} \text {. }
$$

After taking into account the dependences (10), (12), the first two operators included in equation (6) are as follows

$$
\mathrm{L}_{1}^{1}=\zeta_{1}^{-1} G_{12} D_{23} \Delta_{1}, \quad \mathrm{~L}_{2}^{1}=D_{13} G_{12} \Delta_{1}
$$

Where

$$
\Delta_{1}=\frac{\partial^{2}}{\partial x_{1}^{2}}+\zeta_{1} \frac{\partial^{2}}{\partial x_{2}^{2}}+\chi_{1} \frac{\partial^{2}}{\partial x_{3}^{2}}, \quad \chi_{1}=\zeta_{1} \frac{G_{13}}{G_{12}}
$$

Let us consider the expression of the operators (14) and write down the first equation (6)

$$
\Delta_{1}\left[\frac{\partial}{\partial x_{2}} \mathrm{u}_{1}-s_{1} \frac{\partial}{\partial x_{1}} \mathrm{u}_{2}\right]=0
$$

which solution is

$$
\mathrm{u}_{1}=s_{1} \frac{\partial^{2} \Phi}{\partial x_{1} \partial x_{3}}+\varphi_{1}, \quad \mathrm{u}_{2}=\frac{\partial^{2} \Phi}{\partial x_{2} \partial x_{3}}+\varphi_{2}
$$

where $\Phi$ is unknown function, and functions $\varphi_{j}$ satisfy equation (15): $\Delta_{1} \varphi_{j}=0$.

Let us substitute dependence (16) into equation (1), take into account conditions (9), (10), (13) and obtain a system of two equations

$$
\begin{gathered}
\frac{\partial}{\partial x_{3}}\left[L_{4} \Phi+D_{23} \mathrm{u}_{3}\right]=-\frac{D_{12}}{D_{13}}\left[D_{13} \frac{\partial \varphi_{1}}{\partial x_{1}}+D_{23} \frac{\partial \varphi_{2}}{\partial x_{2}}\right], \\
\frac{\partial^{2}}{\partial x_{3}^{2}}\left\{s_{1} D_{13} \frac{\partial^{2}}{\partial x_{1}^{2}}+D_{23} \frac{\partial^{2}}{\partial x_{2}^{2}}\right\} \Phi+L_{3} \mathrm{u}_{3}=-\frac{\partial}{\partial x_{3}}\left[D_{13} \frac{\partial \varphi_{1}}{\partial x_{1}}+D_{23} \frac{\partial \varphi_{2}}{\partial x_{2}}\right]
\end{gathered}
$$

where the notation is entered

$$
L_{4}=\zeta_{1} \mathrm{~B}_{11} \Delta_{4}, \quad \Delta_{4}=\left[\frac{\partial^{2}}{\partial x_{1}^{2}}+\frac{\mathrm{B}_{22}}{\zeta_{1} \mathrm{~B}_{11}} \frac{\partial^{2}}{\partial x_{2}^{2}}+\frac{G_{13}}{\mathrm{~B}_{11}} \frac{\partial^{2}}{\partial x_{3}^{2}}\right]
$$


Since the function $\Phi$ does not depend on the functions ${ }^{\varphi_{j}}$, then the right-hand sides of equations (17) will be zero. From this condition we define functions $\varphi_{j}$

$$
\varphi_{1}=D_{23} \frac{\partial \psi_{1}}{\partial x_{2}}, \quad \varphi_{2}=-D_{13} \frac{\partial \psi_{1}}{\partial x_{1}}, \quad \Delta_{1} \psi_{1}=0
$$

From the system of equations (17) with zero right-hand side, the defining equation is found in partial derivatives of the fourth order for the required function $\Phi$

$$
\frac{1}{B_{11} G_{23}}\left\{L_{3} L_{4}-D_{23} \frac{\partial^{2}}{\partial x_{3}^{2}}\left[s_{1} D_{13} \frac{\partial^{2}}{\partial x_{1}^{2}}+D_{23} \frac{\partial^{2}}{\partial x_{2}^{2}}\right]\right\} \Phi=\Omega \Phi=0
$$

Where

$$
\begin{gathered}
\Omega=\frac{\partial^{4}}{\partial x_{1}^{4}}+p_{2} \frac{\partial^{4}}{\partial x_{1}^{2} \partial x_{2}^{2}}+p_{3} \frac{\partial^{4}}{\partial x_{2}^{4}}+p_{4} \frac{\partial^{4}}{\partial x_{1}^{2} \partial x_{3}^{2}}+p_{5} \frac{\partial^{4}}{\partial x_{2}^{2} \partial x_{3}^{2}}+p_{6} \frac{\partial^{4}}{\partial x_{3}^{4}}, \\
p_{2}=\zeta_{1}+\zeta_{1}^{-1} \frac{\mathrm{B}_{22}}{B_{11}}, \quad p_{3}=\frac{\mathrm{B}_{22}}{B_{11}}, \quad p_{4}=\frac{G_{13}}{B_{11}}+\frac{1}{G_{13}}\left(\mathrm{~B}_{33}-\frac{D_{13}^{2}}{B_{11}}\right), \\
p_{5}=\frac{\mathrm{G}_{13}}{B_{11}} \zeta_{1}+\frac{1}{B_{11} \zeta_{1} G_{13}}\left(\mathrm{~B}_{33} \mathrm{~B}_{22}-\kappa_{1}^{2} D_{13}^{2}\right) \quad p_{6}=\frac{\mathrm{B}_{33}}{B_{11}},
\end{gathered}
$$

Let us use formulas (16), (18) and find expression of displacements

$$
\mathrm{u}_{1}=s_{1} \frac{\partial^{2} \Phi}{\partial x_{1} \partial x_{3}}+\kappa_{1} \mathrm{D}_{13} \frac{\partial \psi_{1}}{\partial x_{2}}, \quad \mathrm{u}_{2}=\frac{\partial^{2} \Phi}{\partial x_{3} \partial x_{2}}-D_{13} \frac{\partial \psi_{1}}{\partial x_{1}} \quad \mathrm{u}_{3}=-\frac{1}{D_{23}} L_{4} \Phi
$$

It should be noted that the solution (21) obtained in the assumption is $\mathrm{L}_{3}^{1} \neq s_{2} \mathrm{~L}_{1}^{1}$.

Let us take into account the representation of displacements (21) and determine the deformation by formulas (5), and find the stress by formulas (4).

The representation of solution (21) does not contain redundant functions, since function $\Phi$ satisfies the equation of the fourth order, and the function $\psi_{1}$ satisfies the equation of the second order, which is equivalent to three functions satisfying the equation of the second order on partial derivatives.

It is determined that in contrast to equations with partial derivatives of two variables or two expressions of derivatives, the operator (20) of the fourth order of three variables $x_{k}$, $k=\overline{1,3}$ contains three independent derivatives and, in general case, is not decomposed into two operator factors.

Proof by contradiction. Let us assume that in the general case there is the decomposition of the operator (20) into two factors (operators) of the second order with valid coefficients. 
After dividing each factor by the corresponding coefficient near the derivative $\frac{\partial^{2}}{\partial x_{1}^{2}}$, two second-order operators will have two independent coefficients, respectively, and operator (20) - five independent coefficients. Since we cannot choose four coefficients in such a way as their combinations was equal to five coefficients, then this equality (in the general case) is not be fulfilled. We have received a contradiction that proves the statement. The case of complexconjugate coefficients is proved in similar way.

Let us find under what additional conditions the operator (20) can be decomposed into two factors. Let us suppose that there is such decomposition into two factors with valid coefficients. Then for the operator (20) we write down the following equation

$$
\begin{aligned}
\Omega & =\Delta_{2} \Delta_{3}=\left(\frac{\partial^{2}}{\partial x_{1}^{2}}+\zeta_{2} \frac{\partial^{2}}{\partial x_{2}^{2}}+\chi_{2} \frac{\partial^{2}}{\partial x_{3}^{2}}\right)\left(\frac{\partial^{2}}{\partial x_{1}^{2}}+\zeta_{3} \frac{\partial^{2}}{\partial x_{2}^{2}}+\chi_{3} \frac{\partial^{2}}{\partial x_{3}^{2}}\right)= \\
& =\frac{\partial^{4}}{\partial x_{1}^{4}}+h_{2} \frac{\partial^{4}}{\partial x_{1}^{2} \partial x_{2}^{2}}+h_{3} \frac{\partial^{4}}{\partial x_{2}^{4}}+h_{4} \frac{\partial^{4}}{\partial x_{1}^{2} \partial x_{3}^{2}}+h_{5} \frac{\partial^{4}}{\partial x_{2}^{2} \partial x_{3}^{2}}+h_{6} \frac{\partial^{4}}{\partial x_{3}^{4}},
\end{aligned}
$$

where $\zeta_{j}, \chi_{j}$ are actual coefficients,

$$
h_{2}=\zeta_{2}+\zeta_{3}, h_{3}=\zeta_{3} \zeta_{2}, h_{4}=\chi_{3}+\chi_{2}, h_{5}=\chi_{2} \zeta_{3}+\chi_{3} \zeta_{2}, h_{6}=\chi_{2} \chi_{3}
$$

Let us compare the coefficients near the same derivatives in operators (20) and (22) and obtain the system of five equations in order to find the decomposition coefficients: $\zeta_{j}, \chi_{j}$, $j=\overline{2,3}$

$$
h_{j}=p_{j}, j=\overline{2,6} \text {. }
$$

Let us write down separately the first and second and third and fourth equations (23) and reduce them to quadratic equations

$$
\zeta_{2}^{2}-p_{2} \zeta_{2}+\frac{\mathrm{B}_{22}}{B_{11}}=0 \quad \chi_{2}^{2}-p_{4} \chi_{2}+\frac{\mathrm{B}_{33}}{B_{11}}=0
$$

and have found their solutions:

$$
\zeta_{2}=\zeta_{1}, \quad \zeta_{3}=\zeta_{1}^{-1} \frac{\mathrm{B}_{22}}{B_{11}}, \chi_{2}=\frac{p_{4} \pm \sqrt{D}}{2}, \chi_{3}=p_{4}-\chi_{2}
$$

where $D=p_{4}^{2}-4 \frac{\mathrm{B}_{33}}{B_{11}}$. The fourth equation (23) is as follows

$$
p_{5}=\chi_{2} \zeta_{3}+\chi_{3} \zeta_{2}=\chi_{2}\left(p_{2}-\zeta_{2}\right)+\zeta_{2}\left(p_{4}-\chi_{2}\right)
$$


Taking into account conditions (24) and mathematical transformations of equation (25), we obtain the following additional equation

$$
p_{5}\left(p_{4} p_{2}-p_{5}\right)-p_{4}{ }^{2} \frac{\mathrm{B}_{22}}{B_{11}}=\frac{\mathrm{B}_{33}}{B_{11}}\left(\zeta_{1}-\zeta_{1}^{-1} \frac{\mathrm{B}_{22}}{B_{11}}\right)^{2}
$$

which sets a constraint on the values of orthotropic parameters $G_{13}, D_{13}$, at which the decomposition is possible (22).

Equation (26) is satisfied for transversely isotropic material.

Let us set down the notation of operators (14), (22) with coefficients (24)

$$
\Delta_{j}=\frac{\partial^{2}}{\partial x_{1}^{2}}+\zeta_{j} \frac{\partial^{2}}{\partial x_{2}^{2}}+\chi_{j} \frac{\partial^{2}}{\partial x_{3}^{2}}, j=\overline{1,3} .
$$

Let us consider the expression of the second-order operators (27), included in representation (22) and write down the solution of equation (19), (20)

$$
\Phi=\psi_{2}+\psi_{3}, \quad \Delta_{j} \psi_{j}=0, j=\overline{1,3} .
$$

Let us use representation (28) and write down displacements (21)

$$
\begin{gathered}
\mathrm{u}_{1}=s_{1} \frac{\partial^{2}\left(\psi_{2}+\psi_{3}\right)}{\partial x_{1} \partial x_{3}}+\kappa_{1} \frac{\partial \psi_{1}}{\partial x_{2}} \quad \mathrm{u}_{2}=\frac{\partial^{2}\left(\psi_{2}+\psi_{3}\right)}{\partial x_{2} \partial x_{3}}-\frac{\partial \psi_{1}}{\partial x_{1}}, \\
\mathrm{u}_{3}=-\frac{1}{D_{23}} L_{4}\left(\psi_{2}+\psi_{3}\right)
\end{gathered}
$$

Let us take into account expressions (29) and determine deformations by formuli (5)

$$
\begin{gathered}
\varepsilon_{1}=s_{1} \frac{\partial^{3}\left(\psi_{2}+\psi_{3}\right)}{\partial x_{1}^{2} \partial x_{3}}+\kappa_{1} \frac{\partial^{2} \psi_{1}}{\partial x_{1} \partial x_{2}} \quad \varepsilon_{2}=\frac{\partial^{3}\left(\psi_{2}+\psi_{3}\right)}{\partial x_{2}^{2} \partial x_{3}}-\frac{\partial^{2} \psi_{1}}{\partial x_{1} \partial x_{2}}, \\
\varepsilon_{3}=-\frac{\zeta_{1} \mathrm{~B}_{11}}{D_{23}} \Delta_{4} \frac{\partial\left(\psi_{2}+\psi_{3}\right)}{\partial x_{3}}, \\
\gamma_{12}=\left(s_{1}+1\right) \frac{\partial^{3}\left(\psi_{2}+\psi_{3}\right)}{\partial x_{1} \partial x_{2} \partial x_{3}}+\kappa_{1} \frac{\partial^{2} \psi_{1}}{\partial x_{2}^{2}}-\frac{\partial^{2} \psi_{1}}{\partial x_{1}^{2}}, \\
\gamma_{13}=s_{1} \frac{\partial^{3}}{\partial x_{1} \partial x_{3}^{2}}\left(\psi_{2}+\psi_{3}\right)+\kappa_{1} \frac{\partial^{2} \psi_{1}}{\partial x_{2} \partial x_{3}}-\frac{\zeta_{1} \mathrm{~B}_{11}}{D_{23}} \Delta_{4} \frac{\partial\left(\psi_{2}+\psi_{3}\right)}{\partial x_{1}} \\
\gamma_{23}=\frac{\partial^{3}}{\partial x_{2} \partial x_{3}^{2}}\left(\psi_{2}+\psi_{3}\right)-\frac{\partial^{2} \psi_{1}}{\partial x_{1} \partial x_{3}}-\frac{\zeta_{1} \mathrm{~B}_{11}}{D_{23}} \Delta_{4} \frac{\partial\left(\psi_{2}+\psi_{3}\right)}{\partial x_{2}} .
\end{gathered}
$$


Let us substitute the expression of deformations (30) into formulae (4) and find the stresses.

Let us consider transversely isotropic material for which: $\kappa_{1}=1, B_{11}=B_{22}, \zeta_{1}=1$, $s_{1}=1$. The expression of displacements follows from equations (12)-(14), (27), (29)

$$
\begin{gathered}
\mathrm{u}_{1}=\frac{\partial^{2}\left(\psi_{2}+\psi_{3}\right)}{\partial x_{1} \partial x_{3}}+\frac{\partial \psi_{1}}{\partial x_{2}}, \quad \mathbf{u}_{2}=\frac{\partial^{2}\left(\psi_{2}+\psi_{3}\right)}{\partial x_{2} \partial x_{3}}-\frac{\partial \psi_{1}}{\partial x_{1}} \\
\mathrm{u}_{3}=m_{2} \frac{\partial^{2} \psi_{2}}{\partial x_{3}^{2}}+m_{3} \frac{\partial^{2} \psi_{3}}{\partial x_{3}^{2}}
\end{gathered}
$$

where $m_{j}=\frac{1}{D_{13}}\left(\mathrm{~B}_{11} \chi_{j}-G_{13}\right)$. If we introduce notation $\varphi_{j}=\frac{\partial \psi_{j}}{\partial x_{3}}, j=\overline{2,3}$, then representations (31) have coincided with the displacements given in [5, 6] for transversely isotropic material.

It should be noted that the proposed approach and obtained formulas make it possible to set and solve the corresponding boundary value problems and determine of threedimensional stress-strain state of different orthotropic bodies.

Conclusions. The solution of equations for the theory of elasticity of orthotropic body can be simplified by imposing some restrictions on the ratio of the shear modules and the modules of perpendicular expansion. Criteria determining such class of orthotropic materials that their stress-strain state can be expressed by two second- and fourth-order functions are defined. The obtained equations depend on seven independent elastic constants describing orthotropic material. It is determined that equation of the fourth order, in general case, is not decomposed into two operator factors. The equation is obtained that must be satisfied by the shear modulus of an orthotropic material so that the fourth-order equation can be decomposed into the product of two second-order equations.

\section{References}

1. Lekhnitskii S. G. Theory of elasticity of an anisotropic body. Moscow: Mir Publishers, 1981, 430 p.

2. Rand O, Rovenski V. Analytical Methods in Anisotropic Elasticity, Springer Science \& Business Media, 2007, 452 p. ISBN 978-0-8176-4420-8.

3. Ting T. C. T. Anisotropic elasticity theory and applications, New York, Oxford, Oxford university press, 1996. DOI: https://doi.org/10.1093/oso/9780195074475.001.0001

4. Revenko V. P. Presentation of a general 3D solution of equations of elasticity theory for a wide class of orthotropic materials // Scientific journal of the Ternopil national technical university. No. 3 (95). 2019. P. 49-54. DOI: https://doi.org/10.33108/visnyk_tntu2019.03.049

5. Elliot H. A. Axial symmetric stress distributions in allotropic hexagonal crystals. The problem of the plane and related problems, Math. Proc. Cambridge Phil. Soc. 45. No. 4. 1949. P. 621-630. DOI: https://doi.org/10.1017/S0305004100025305

6. Hu H. C. On the the three-dimensional problems of elasticity of a transversely isotropic body, Data Sci. Sinica, Vol. 2, 1953, pp.145-151.

7. Baida É. N., General solution of the equilibrium equations of anisotropic and isotropic bodies, Izv. Vyssh. Uchebn. Zaved., Stroit. Arkhitekt, No. 6, 1968, pp. 17-27.

8. Timoshenko S. P. and Goodier J. N. Theory of Elasticity. New York: McGraw-Hill. 1970. 586 pp.

9. Revenko V. P. Solving the three-dimensional equations of the linear theory of elasticity // Int. Appl. Mech. Vol. 45, 2009, pp. 730-741. DOI: https://doi.org/10.1007/s10778-009-0225-4

10. Revenko V. P., Bakulin V. N. Solving equations of 3D elasticity for orthotropic bodies. Journal of Physics: Conference Series: Materials Science and Engineering 927012052 IOP Publishing, 2020, pp. 7. DOI: https://doi.org/10.1088/1757-899X/927/1/012052

\section{Список використаної літератури}

1. Lekhnitskii S. G., Theory of elasticity of an anisotropic body. Moscow: Mir Publishers, 1981. 430 p.

2. Rand O, Rovenski V. Analytical Methods in Anisotropic Elasticity. Springer Science \& Business Media, 2007. 452 p. ISBN 978-0-8176-4420-8. 
3. T. C. T. Ting, Anisotropic elasticity theory and applications. (Oxford university press, New York, Oxford, 1996). DOI: https://doi.org/10.1093/oso/9780195074475.001.0001

4. Revenko V. P. Presentation of a general 3D solution of equations of elasticity theory for a wide class of orthotropic materials. Scientific journal of the Ternopil national technical university. 2019. No. 3 (95). P. 49-54. DOI: https://doi.org/10.33108/visnyk_tntu2019.03.049

5. Elliot H. A. Axial symmetric stress distributions in allotropic hexagonal crystals. The problem of the plane and related problems. Math. Proc. Cambridge Phil. Soc. 1949. 45. No. 4. P. 621-630. DOI: https://doi.org/10.1017/S0305004100025305

6. Hu H. C. On the the three-dimensional problems of elasticity of a transversely isotropic body. Data Sci. Sinica. 1953. 2. P. 145-151.

7. Baida É. N., General solution of the equilibrium equations of anisotropic and isotropic bodies, Izv. Vyssh. Uchebn. Zaved., Stroit. Arkhitekt. 1968, No. 6, 17-27.

8. Timoshenko S. P. and Goodier J. N. 1970 Theory of Elasticity (New York: McGraw-Hill) 586 p.

9. Revenko V. P. Solving the three-dimensional equations of the linear theory of elasticity. Int. Appl. Mech. 2009. 45. P. 730-741. DOI: https://doi.org/10.1007/s10778-009-0225-4

10. Revenko V. P., Bakulin V. N. Solving equations of 3D elasticity for orthotropic bodies. Journal of Physics: Conference Series: Materials Science and Engineering 927012052 IOP Publishing, 2020, pp. 7. DOI: https://doi.org/10.1088/1757-899X/927/1/012052

\title{
УДК 539.3
}

\section{ПРЕДСТАВЛЕННЯ НАПРУЖЕНОГО СТАНУ ДЕЯКИХ ОРТОТРОПНИХ МАТЕРІАЛІВ ТРЬОМА ГАРМОНІЧНИМИ ФУНКЦІЯМИ ВІД ТРЬОХ ЗМІННИХ}

\section{Віктор Ревенко}

\author{
Інститут прикладних проблем механіки і математики \\ імені Я. С. Підстригача НАН Украӥни, Львів, Украӥна
}

Резюме. Розв'язано рівняння статичної теорії пружності для деякого класу ортотропних матеріалів. Для описування їх напруженого стану використано лінійну математичну модель тривимірного ортотропного тіла, за відсутності об' 'мних сил. Розглянуто модель деформованого тіла на базі подання напружень через переміщення й диференціальні рівняння рівноваги пружного тіла. Записано три рівняння, які описують пружну рівновагу ортотропного тіла через пружні переміщення в декартовій системі координат. Модель залежить від дев'яти незалежних постійних і може описувати різні ортотропні, а також трансверсально-ізотропний та ізотропний матеріали. Використано методику інтегрування трьох рівнянь, иляхом почергового виключення переміщень. Розглянуто питання, пов'язані з усуненням зайвих функиій із падання загального розв'язку рівнянь теорії пружності. Знайдено критерії, які визначають такий клас ортотропних матеріалів, щуо їх напружено-деформований стан можна виразити через дві функиї. Одна функиія задовольняє рівняння в частинних похідних другого порядку, а інша - четвертого порядку. Встановлено, щуо рівняння четвертого порядку, в загальному випадку, не розкладається на два операторних множники. Отримані рівняння залежать від семи незалежних пружних постійних, щэо описують ортотропний матеріал за незначних обмежень на два модулі зсуву. Знайдено рівняння, яке має задовольняти пружні константи ортотропного матеріалу, так щзоб рівняння четвертого порядку можна було розкласти на добуток двох рівнянь другого порядку. Цей розклад дозволяє представити переміщення пружного ортотропного тіла через три гармонічних у різних декартових системах координат функиї. Отримано загальне представлення напружено-деформованого стану ортотропного матеріалу через введені три гармонічних функиї переміщень. Запропонована модель залежить від шести незалежних пружних сталих, а три інших коефіцієнти ортотропії визначаються з отриманих квадратних рівнянь. На основі загального розв'язку рівнянь рівноваги ортотропного тіла записано вираз деформачій $і$ напружень через введені гармонічні функиї. Отримані результати можна використати при розрахунку й практичному проектуванні елементів конструкцій із ортотропних матеріалів.

Ключові слова: ортотропні матеріали, рівняння рівноваги, переміщення, напруження, модулі зсуву.

https://doi.org/10.33108/visnyk_tntu2020.04.020

Отримано 10.10.2020 